\title{
IMPLEMENTASI STEAM DALAM PEMBELAJARAN MATEMATIKA
}

\author{
Iik Nurhikmayati \\ Pendidikan Matematika, FKIP, Universitas Majalengka \\ ik.nurhikmayati@gmail.com
}

\begin{abstract}
Abstrak-Dalam menghadapi era globalisasi, penguasaan ilmu pengetahuan dan teknologi menjadi suatu keharusan. Hal tersebut menuntut berbagai pihak untuk dapat mengembangkan kemampuan yang berhubungan dengan pengembangan kemampuan di bidang teknologi. Dalam bidang pendidikan, salah satu terobosan pendidikan di Indonesia yang berupaya mengembangkan manusia yang bisa menciptakan ekonomi berbasis sains dan teknologi adalah pembelajaran STEAM. STEAM sebagai sebuah pendekatan pembelajaran merupakan sarana bagi peserta didik untuk menciptakan ide/gagasan berbasis sains dan teknologi melalui kegiatan berpikir dan bereksplorasi dalam memecahkan masalah berdasarkan pada lima disiplin ilmu yang terintegrasi. Implementasi STEAM dalam pembelajaran merupakan sebuah proses penerapan ide, gagasan dan konsep yang terkandung dalam meta disiplin ilmu dalam sebuah pembelajaran yang diharapkan dapat meningkatkan kemampuan baik dalam aspek kognitif, afektif maupun psikomotor peserta didik dalam menghadapai kemajuan teknologi. Dalam penelitian ini akan dibahas bagaimana implementasi STEAM dalam pembelajaran di sekolah, khususnya dalam pembelajaran matematika serta bagaimana contohnya. Penelitian ini bertujuan untuk memberikan manfaat pengetahuan terkait STEAM dan implementasinya dalam pembelajaran matematika di sekolah, baik bagi guru dan dosen sebagai pelaku pembelajaran.
\end{abstract}

Kata kunci: Implementasi, Matematika, STEAM 


\section{PENDAHULUAN}

Desawa ini berbagai aktivitas hidup telah didominasi oleh produk berteknologi tinggi. Tidak sedikit dari kita yang tidak bisa hidup tanpa teknologi. Hal ini menandakan bahwa perkembangan sains dan teknologi yang sangat cepat tak dapat dihindari tetapi harus dihadapi dan dikuasai. Dalam menghadapi era globalisasi, penguasaan ilmu pengetahuan dan teknologi menjadi suatu keharusan. Hal tersebut menuntut berbagai pihak untuk dapat mengembangkan kemampuan yang berhubungan dengan pengembangan kemampuan di bidang teknologi. Dalam bidang pendidikan, tentu saja pengembangan kemampuan siswa dalam menguasai teknologi telah diupayakan pada setiap pembaruan kurikulum yang dilakukan pemerintah guna memperoleh generasi bangsa yang siap dan handal dalam menghadapi era globalisasi. Salah satu terobosan pendidikan di Indonesia yang berupaya mengembangkan manusia yang bisa mencipatkan ekonomi berbasis sains dan teknologi adalah pembelajaran STEAM (wijaya, 2015). Pembelajaran STEAM (Science, Technology, Engineering, Arts, and Mathematics) merupakan sebuah integrasi dari berbagai disiplin ilmu yaitu sains, teknologi, teknik, seni dan matematika yang berada dalam satu kesatuan pendekatan pembelajaran. Buinicontro (2017) mendefinisikan STEAM sebagai integrasi disipilin ilmu seni ke dalam kurikulum dan pembelajaran pada wilayah sains, teknologi, teknik dan matematika yang telah dikenal sebelumnya sebagai (STEM). STEAM merupakan meta disiplin ilmu yang mengintegrasikan sains, teknologi, teknik, seni dan matematika menjadi sebuah pendekatan terpadu yang dapat diimplementasikan dalam pembelajaran di sekolah.
STEAM sebagai sebuah pendekatan pembelajaran merupakan sarana bagi peserta didik untuk menciptakan ide/gagasan berbasis sains dan teknologi melalui kegiatan berpikir dan bereksplorasi dalam memecahkan masalah berdasarkan pada lima disiplin ilmu yang terintegrasi. Jika pemecahan masalah dilakukan berdasarkan beberapa disiplin ilmu, maka akan menghasilkan sebuah solusi yang sangat tepat, tidak hanya pemecahan masalah matematik namun berdasarkan konsep yang berhubungan dengan disipilin ilmu lain sehingga pemecahan masalah akan menjadi sangat menarik, efektif dan efisien.

Pada pembaruan kurikulum 2013 yang telah ditetapkan pemerintah, peserta didik diharapkan akan mampu memiliki kemampuan hidup sebagai pribadi dan warga negara yang beriman, produktif, kreatif, inovatif, dan efektif serta mampu berkontribusi pada kehidupan bermasyarakat, berbangsa, bernegara dan peradaban dunia (Permendikbud, 2013). Harapan dan tujuan pendidikan pada kurikulum 2013 tersebut dapat dilaksanakan melalui pendekatan pembelajaran berbasis STEAM yang menawarkan pendidikan meta dispilin ilmu dalam mengembangkan kemampuan berpikir dan kreativitas dalam memecahkan masalah. Hal ini sejalan dengan pendapat Buinicontro (2017) yang menyatakan bahwa integrasi pada STEAM akan dapat memberikan kesempatan baru kepada peserta didik untuk melakukan proses pembelajaran desain secara langsung dan menghasilkan produk dengan kemampuan kreativitas dan pemecahan masalah yang baik. Kreativitas dan kemampuan berpikir menjadi dua aspek penting yang harus dimiliki peserta didik guna menghadapi era globalisasi yang semakin tinggi. Shadiq (2019) 
menyatakan sebagai akibat dari aplikasi industry 4.0 adalah ketimpangan yang semakin besar, sehingga dua aspek penting yang harus menjadi perhatian guru adalah kreativitas dan berpikir kritis. Oleh karena itu, dalam upaya mengembangkan kemampuan berpikir tingkat tinggi sekaligus mengembangkan kreativitas, implementasi STEAM dalam pembelajaran menjadi sangat dibutuhkan, khususnya dalam pembelajaran matematika di sekolah.

Implementasi adalah proses penerapan ide, konsep, kebijakan atau inovasi dalam suatu tindakan praktis sehingga memberikan dampak, baik berupa perubahan pengetahuan, keterampilan, maupun nilai dan sikap. Implementasi sebuah pendekatan pembelajaran merupakan proses penerapan ide dan konsep sebuah pendekatan dalam suatu pembelajaran yang akan memberikan pengaruh dan peningkatan pendidikan ke arah yang lebih baik. Implementasi STEAM dalam pembelajaran merupakan sebuah proses penerapan ide, gagasan dan konsep yang terkandung dalam meta disiplin ilmu dalam sebuah pembelajaran yang diharapkan dapat meningkatkan kemampuan baik dalam aspek kognitif, afektif maupun psikomotor peserta didik dalam menghadapai kemajuan teknologi. Dalam penelitian ini akan dibahas bagaimana implementasi STEAM dalam pembelajaran di sekolah, khususnya dalam pembelajaran matematika. Konsep dan prinsip apa saja yang dapat digunakan dalam mengimplementasikan STEAM dalam pembelajaran matematika dan bagaimana contoh penerapannya akan menjadi kajian dalam penelitian ini. Penelitian ini bertujuan untuk memberikan manfaat pengetahuan terkait STEAM dan implementasinya dalam pembelajaran matematika di sekolah, baik bagi guru dan dosen sebagai fasilitator pembelajaran dan peserta didik sebagai pelaku pembelajaran.

\section{KAJIAN LITERATUR \\ a. Pembelajaran Matematika}

Matematika merupakan salah satu ilmu pengetahuan yang sering ditemui dalam aktivitas sehari-hari. Matematika sangat berguna dalam menunjang aktivitas manusia dalam memenuhi kebutuhan hidupnya dan sering digunakan dalam berbagai bidang usaha. Oleh karena itu, matematika menjadi salah satu ilmu pengetahuan yang sangat penting untuk dikuasai dengan baik.

Matematika merupakan ilmu pengetahuan yang memuat suatu kumpulan konsep berupa operasi, angka, symbol dan pola yang pasti. Menurut Hendriana dan Sumarmo (2014), matematika memuat suatu kumpulan konsep dan operasi-operasi, tetapi di dalam pembelajaran matematika pemahaman siswa mengenai hal-hal tersebut lebih objektif dibanding mengembangkan kekuatannya dalam perhitunganperhitungannya. Oleh karena itu, dalam pembelajaran matematika tidak hanya mengembangkan kemampuan kognitif dalam arti pandai menghitung, akan tetapi pembelajaran matematika dapat mengembangkan beberap aspek baik itu aspek kognitif, afektif maupun psikomotor.

Pembelajaran matematika adalah suatu aktivitas mental untuk memahami arti dan hubunganhubungan serta simbol-simbol kemudian diterapkan pada situasi nyata (Fitri, 2014). Aktivitas tersebut akan mendorong peserta didik dalam mengembangkan 
pemahamannya terhadap situasi dan mendapatkan solusi untuk permasalahan yang dihadapi. Tidak hanya pada konteks belajar, kemampuan menyelesaikan masalah dapat juga diaplikasikan untuk menyelesaikan masalah dalam kehidupan sehari-hari.

NCTM (National Council of Teacher of Mathematics) merekomendasikan 4 (empat) prinsip pembelajaran matematika, yaitu:

1) Matematika sebagai pemecahan masalah

2) Matematika sebagai penalaran

3) Matematika sebagai komunikasi, dan

4) Matematika sebagai hubungan. (Suherman, 2003)

\section{b. STEAM}

STEAM yang merupakan kepanjangan dari istilah Sains, Technology, Engeenering, Arts and Mathematics adalah sebuah terobosan dalam dunia pendidikan yang mengintegrasikan beberapa elemen ilmu pengetahuan dalam satu kesatuan konsep pembelajaran. STEAM lahir dan berperan setelah didefinisikannya konsep STEM (Sains, Technology, Engeenering and Mathematics) terlebih dahulu. STEAM lahir dan muncul setelah adanya penambahan disiplin ilmu Seni (art) yang terintegrasi pada STEM. Buinicontro (2017) mendefinisikan STEAM sebagai integrasi disiplin ilmu seni ke dalam kurikulum dan pembelajaran pada wilayah sains, teknologi, teknik dan matematika (STEM). Sedangkan menurut Brown, dkk (2011) STEM adalah meta disiplin di tingkat sekolah dimana guru sains, teknologi, teknik dan matematika mengajar pendekatan terpadu dan masing-masing materi disiplin tidak dibagi-bagi tapi ditangani dan diperakukan sebagai satu kesatuan yang dinamis. Oleh karena itu dapat dikatakan bahwa STEAM merupakan meta disiplin ilmu yang mengintegrasikan sains, teknologi, teknik, seni dan matematika menjadi sebuah pendekatan terpadu yang dapat diimplementasikan dalam pembelajaran di sekolah.

Meskipun STEM dan STEAM lahir dan berkembang sejalan, namun ada kebutuhan dasar yang mendefinisikan STEAM lebih baik, hal ini karena out come yang dihasilkan dari pendidikan STEAM diharapkan dapat memunculkan nilai seni yang sebelumnya tidak terdapat pada pendidikan STEM. Integrasi pada STEAM akan dapat memberikan kesempatan baru kepada peserta didik untuk dapat melakukan proses pembelajaran desain secara langsung dan menghasilkan produk dengan kemampuan kreativitas dan pemecahan masalah yang baik Buinicontro (2017).

\section{METODE PENELITIAN}

Metode yang digunakan dalam penelitian ini adalah metode telaah pustaka. Metode telaah pustaka adalah kajian kritis atas pembahasan suatu topic yang sudah ditulis oleh para peneliti atau ilmuan di dalam berbagai sumber. Sumber informasi dapat berupa buku, jurnal, ebook, ataupun artikel ilmiah lainnya. Langkahlangkah penulisan yang dilakukan adalah: a) pengumpulan data mengenai STEAM dan bagaimana implementasinya dalam pembelajaran di sekolah; b) menganalisis data yang diperoleh berdasarkan pemikiran penulis; dan c) menyimpulkan hasil analisis telaah pustaka.

\section{HASIL DAN PEMBAHASAN Apa itu STEAM?}


STEAM didefinisikan dengan cara berbeda oleh setiap ahli. Akan tetapi semua definisi tersebut merujuk pada satu kesimpulan bahwa STEAM merupakan meta disiplin ilmu yang mengintegrasikan sains, teknologi, teknik, seni dan matematika menjadi sebuah pendekatan terpadu yang dapat diimplementasikan dalam pembelajaran di sekolah. Buinicontro (2017) mendefinisikan STEAM sebagai integrasi disiplin ilmu seni ke dalam kurikulum dan pembelajaran pada wilayah sains, teknologi, teknik dan matematika (STEM). Unsur seni dipadukan pada STEM sebagai dasar akan kebutuhan lain yang lebih baik dan menarik agar outcome atau produk yang dihasilkan dari pembelajaran berbasis STEAM memuat unsur seni yang tentunya akan memberikan pengaruh positif bagi siapa saja yang menikmatinya.

Integrasi unsur seni dalam STEAM dapat memberikan kesempatan kepada peserta didik untuk berkreasi dan berinovasi dalam bentuk kreativitas seni yang dipadukan dalam outcome pembelajaran. Produk STEAM tidak hanya memuat aspek kognitif, namun akan memuat beberapa aspek lain yaitu afektif dan spikomotor yang dapat dikembangkan secara general oleh peserta didik dalam menghadapi era revolusi industry 4.0. Kompleksitas abad 21 dewasa ini menuntut kemampuan dari berbagai bidang dan pembelajaran berbasis STEAM dapat menjadi persiapan dan latihan menghadapi semuanya (Wijaya dkk, 2015). Oleh karena itu, kemampuan kognitif dan kreativitas harus terus dikembangkan dalam berbagai bentuk salah satunya melalui pembelajaran berbasis STEAM yang mengintegrasikan desain, kreativitas dan inovasi pada dispilin ilmu sains, teknologi, teknik dan matematika sehingga dapat mengembangkan kemampuan-kemampuan yang dibutuhkan dalam menghadapi globalisasi dan perkembangan ilmu pengetahuan dan teknologi.

\section{Bagaimana implementasi STEAM dalam pembelajaran di sekolah?}

Pembelajaran berbasis STEAM merupakan terobosan baru dalam dunia pendidikan di Indonesia. Belum terlalu banyak guru yang mengimplementasikan STEAM dalam pembelajarannya di sekolah. Perubahan kurikulum di Indonesia sampai pada kurikulum 2013 mengindikasikan adanya perbaikan pendidikan yang dilakukan pemerintah. Kurikulum 2013 yang mengintegrasikan pembelajaran secara tematik akan sangat cocok dipadukan dengan pembelajaran berbasis STEAM. (Wijaya dkk, 2015) menyatakan bahwa sekolah dasar dan menengah pertama adalah tingkat satuan pendidikan yang cocok untuk penerapan pembelajaran berbasis STEAM. Hal ini dikarenakan pada jenjang ini setiap mata pelajaran diajarkan secara tematik terintegrasi.

Pada jenjang sekolah dasar, setiap mata pelajaran di ajarkan berdasarkan tema. Setiap tema dapat memuat beberapa konsep kajian ilmu, diantaranya matematika, IPA, IPS, bahasa Indonesia, teknologi dan lain sebagainya, sehingga pembelajaran berdasarkan tema tersebut dapat diimplementasikan dengan pembelajaran berbasis STEAM. Di akhir pembelajaran, siswa dapat membuat produk hasil pembelajaran yang berhubungan dengan dispilin ilmu yang termuat pada STEAM. Pada jenjang satuan sekolah menengah pertama, beberapa mata pelajaran dipadukan diantaranya IPA terpadu dan IPS terpadu. Matematika juga dapat diajarkan dari berbagai sudut 
pandang disiplin ilmu. Pelajaran pada satuan sekolah pertama lebih kompleks dan dapat dikembangkan berdasarkan kemampuan berpikir peserta didik sehingga pembelajaran berbasis STEAM dapat diimplementasikan. Output hasil pembelajaran berbasis STEAM di jenjang sekolah menengah pertama akan jauh lebih bervariasi, lebih kompleks dan lebih bermakna dibandingkan output pada jenjang sekolah dasar. Begitu pun hal nya implementasi STEAM dapat dilakukan pada jenjang sekolah menengah atas, diantaranya mata pelajaran sains, teknologi, seni dan matematika. Setiap mata pelajaran pada jenjang sekolah menengah atas sudah jelas konsentrasinya, IPA dan IPS tidak lagi menjadi mata pelajaran terpadu melainkan sudah terbagi pada konsentrasi disiplin ilmu masingmasing. STEAM sebagai sebuah pendekatan pembelajaran dapat diimplementasikan pada mata pelajaran yang memiliki keterkaitan dengan disipilin ilmu pada STEAM. Misalnya pelajaran matematika dapat dipelajari dengan menambahkan ilmu teknik dan seni, misalnya mempelajari bangun ruang melalui alat peraga. Alat peraga dapat dibuat siswa melalui integrasi sains, teknik dan seni mendesain. Oleh karena itu, STEAM dapat diimplementasikan pada setiap jenjang pendidikan di sekolah.

Pada pembelajaran berbasis STEAM, seorang guru akan memperoleh tantangan bagaimana mendorong peserta didiknya untuk dapat menggunakan pemahaman dan logikanya secara aktif, berpikir kritis dan kreatif dan menggunakan keterampilan memecahkan masalah. Guru tidak hanya sebagai fasilitator, guru harus ikut berperan serta membangun pemahaman untuk membuat suatu hubungan antar disipilin ilmu yang termuat pada
STEAM. Dalam pembelajaran kelompok STEAM, guru dapat berpindah antar kelompok untuk mengamati, memberikan stimulus dalam bentuk pertanyaan, memberikan pendapat dan saran, serta memberikan nilai terhadap produk yang dihasilkan. Sementara itu, peserta didik bersama dalam sebuah kelompok belajar membangun pemahaman terhadap konsep yang sedang dibahas serta belajar bagaimana membuat koneksi integrasi antar disipilin ilmu dalam STEAM. Pada saat peserta didik dihadapkan pada konsep bangun ruang, mereka harus mampu mengembangkan konsep tersebut pada disipilin ilmu lain. Bangun ruang dapat dibuat dan di desain dengan teknik yang berbeda-beda. Setiap bangun ruang dapat juga di desain dengan menambahkan unsur seni pada setiap pembuatannya, contohnya menambahkan warna pada setiap sisi pada bangun ruang. Pembuatan dan pembelajaran bangun ruang dapat dilakukan dengan menggunakan teknologi softwere matematika, salah satunya adalah geogebra. Implementasi STEAM dalam pembelajaran dapat menghasilkan sebuah produk pembelajaran yang kompleks dan sempurna dalam meningkatkan mutu pendidikan.

\section{Bagaimana implementasi STEAM dalam pembelajaran matematika?}

Matematika merupakan salah satu disiplin ilmu pasti. Kepastian nilai dan makna dalam matematika dapat dipahami sebagai kepastian pada akhir sebuah proses pemecahan masalah, bukan pada proses pembelajaran yang dilalui. Proses pemecahan masalah matematika dapat dilakukan dengan berbagai cara yang berbeda, sehingga cara dalam memecahkan masalah bukan suatu kepastian yang harus 
sama. Pemecahan masalah matematika yang dapat dilakukan dengan cara yang berbeda akan memberikan kesempatan kepada peserta didik mengembangkan kemampuan pemahaman, penalaran, berpikir kritis dan kreatif dalam menghasilkan solusi yang tepat sesuai dengan pengetahuan yang dimilikinya. Kemampuankemampuan tersebut dapat dikembangkan melalui sebuah pembelajaran yang mengarah pada peningkatan berbagai aspek pengetahuan, tidak hanya satu aspek disiplin ilmu tetapi berbagai disiplin ilmu. Integrasi berbagai disiplin ilmu yang termuat dalam sebuah pendekatan pembelajaran salah satunya adalah pendekatan pembelajaran STEAM.

STEAM merupakan meta disiplin ilmu yang dimana guru sains, teknologi, teknik dan matematika mengajar pendekatan terpadu dan masing-masing materi disiplin tidak dibagi-bagi tapi ditangani dan diperlakukan sebagai satu kesatuan yang dinamis (Brorwn, 2011). Implentasi STEAM dalam pembelajaran sekolah telah banyak dilakukan pada berbagai mata pelajaran. Salah satu mata pelajaran yang juga dapat menggunakan STEAM sebagai sebuah pendekatan pembelajaran adalah pelajaran matematika. Bagaimana implementasi STEAM dalam pembelajaran matematika? Dan bagaimana contoh implementasinya? Pertanyaan-pertanyaan ini akan dibahas pada kajian ilmiah ini.

Implementasi STEAM dalam pembelajaran matematika dapat dilakukan dengan baik manakala guru sebagai pendamping pembelajaran telah memahami makna dari sebuah implementasi. Implementasi STEAM merupakan proses penerapan ide dan konsep pendekatan STEAM dalam suatu pembelajaran yang akan memberikan pengaruh dan peningkatan pendidikan ke arah yang lebih baik. Penerapan ide dan konsep STEAM dalam pembelajaran matematika memiliki arti bahwa proses konstruksi konsep matematika yang dilakukan dalam sebuah proses pembelajaran harus diikuti dengan gagasan disiplin ilmu yang termuat dalam STEAM yaitu sains, teknologi, teknik, seni dan matematika. Matematika sendiri merupakan salah satu disipilin ilmu yang terintegrasi pada STEAM, sehingga implementasi STEAM dalam pembelajaran matematika hanya menerapkan gagasan disiplin ilmu lainnya, yaitu sains, teknologi, teknik dan seni.

Dalam pembelajaran matematika, implementasi STEAM dapat dilakukan dengan memahami keterkaitan antara konsep matematika yang ada dengan disiplin ilmu lain yang termuat dalam STEAM. Keterkaitan antar konsep tersebut dapat dibangun melalui kemampuan berpikir kritis, kreatif dan kemampuan pemecahan masalah sehingga akan menghasilkan sebuah ide atau keterampilan kompleks untuk merumuskan sebuah solusi dari masalah yang dihadapi. Implementasi STEAM dilakukan secara terpadu, artinya pendekatan yang dilakukan adalah dengan menghubungkan disipilin ilmu yang termuat dalam STEAM dengan konsep matematika yang ada untuk menghasilkan sebuah ide, gagasan, solusi atau produk. Menurut STEAM dibagi menjadi tiga level atau tingkatan. Pada level 1, proyek yang diberikan bersifat pendek, artinya hanya untuk diselesaikan dalam kurun waktu yang singkat (2-6 periode pembelajaran). Level 2, lama penyelesaian proyek bisa dalam kurun waktu 1-3 bulan dan siswa diminta untuk membuat laporan dalam bentuk e-portopolio, poster, video dan lain sebagainya. Sedangkan pada level 3, 
proyek bersifat long term project yang membutuhkan waktu hingga 5-6 bulan. Peserta didik diminta untuk membuat penelitian/invensi/temuan baik secara individu maupun kelompok (Saputra, 2017). Pembagian level ini dapat diartikan bahwa pembelajaran STEAM tidak jauh berbeda dari pembelajaran berbasis poyek (Project Based Learning), namun berbeda pada konten disipilin ilmu yang diterapkannya.

Beberapa contoh implementasi STEAM dalam pembelajaran matematika diantaranya sebagai berikut:

1) Pembelajaran materi bangun ruang dapat dilakukan dengan menggunakan teknologi softwere matematika dengan teknik pembuatan bangun ruang yang lebih menarik dan lebih mudah. Dalam mendesain bangun ruang, peserta didik dapat menambahkan unsur seni yaitu penambahan warna sehingga bangun ruang yang diperoleh akan lebih menarik untuk di pelajari.

2) Pembelajaran materi peluang dapat dilakukan dengan melakukan proyek pembuatan alat peraga konsep peluang. Peserta didik membuat alat peraga dengan mendesain langsung sesuai dengan pengetahuan dan minatnya. Alat peraga yang di desain dapat dilakukan dengan teknik masingmasing dan peserta didik dapat menambahkan unsur seni pada pembuatan alat peraga tersebut sehingga menarik untuk di pakai. Alat peraga yang dibuat selanjutnya dapat di uji coba pada beberapa soal matematika untuk menyelesaikan masalah.
3) Pembelajaran materi aritmatika social dapat dilakukan dengan membuat produk olahan dari berbagai macam makanan, misalnya buah-buahan atau sayuran. Peserta didik diminta untuk membuat poster, e-poster atau video pendek pada website untuk memasarkan hasil olahan mereka. Peserta didik juga diharuskan melakukan transaksi jual beli pada konsumen yang mereka temui baik secara langsung ataupun secara online. Seluruh aspek disipilin ilmu pada STEAM akan terintegrasi pada pembelajaran ini.

4) Pembelajaran materi trigonometri dapat dilakukan dengan memberikan sebuah proyek. Peserta didik disuruh untuk menghitung sudut elevasi dari sebuah bangunan. Peserta didik secara berkelompok akan mengamati, mengukur dan menganalisis dengan teknik yang berbeda. Pada bidang teknologi, siswa dapat menggunakan internet untuk mencari data-data dalam menyelesaikan proyek tersebut. Hasil proyek dapat dibuat dalam bentuk presentasi dimana peserta didik dapat menambahkan unsur seni pada pembuatan power point yang akan dipresentasikan.

Beberapa contoh implementasi
STEAM dalam pembelajaran
matematika di atas merupakan
sebagian dari seluruh pembelajaran
matematika yang dapat dilakukan
dengan pendekatan STEAM. Masih
banyak materi dan topik matematika


yang dapat diimplementasikan dengan pendekatan pembelajaran STEAM.

Pembelajaran STEAM yang mengintegrasikan beberapa disiplin ilmu dalam satu pembelajaran terpadu menjadi sangat menarik untuk dilakukan. Peserta didik akan lebih termotivasi dalam melakukan pembelajaran matematika karena ragam pembelajaran yang memuat unsur teknologi, teknik dan seni. Oleh karena itu, guru atau dosen dituntut tidak hanya sebagai fasilitator dan penyampai pengetahuan, disamping itu guru dituntut untuk lebih gigih untuk mengidentifikasi dan menentukan pembelajaran seperti apa yang akan digunakan dalam pembelajaran matematika berbasis STEAM. Implementasi STEAM dalam pembelajaran matematika sangat berguna dan bermanfaat, dapat diketahui bahwa tidak hanya aspek kognitif yang dikembangkan, pembelajaran STEAM juga dapat mengembangkan kemampuan dan skill peserta didik untuk menghadapi tantangan era globalisasi di masa mendatang.

\section{KESIMPULAN}

STEAM merupakan meta disiplin ilmu yang mengintegrasikan sains, teknologi, teknik, seni dan matematika menjadi sebuah pendekatan terpadu yang dapat diimplementasikan dalam pembelajaran di sekolah. STEAM dapat diimplementasikan dalam pembelajaran pada setiap jenjang pendidikan. Implementasi STEAM dalam pembelajaran matematika merupakan proses penerapan ide dan konsep STEAM pada pembelajaran matematika. Penerapan ide dan konsep STEAM dalam pembelajaran matematika memiliki arti bahwa proses konstruksi konsep matematika yang dilakukan dalam sebuah proses pembelajaran harus diikuti dengan gagasan disiplin ilmu yang termuat dalam STEAM yaitu sains, teknologi, teknik, seni dan matematika. Terdapat banyak topik matematika yang dapat diterapkan dengan pembelajaran berbasis STEAM diantaranya bangun ruang, peluang, aritmatika social, trigonometri dan lainnya. Implementasi STEAM dalam pembelajaran matematika sangat berguna dan bermanfaat, tidak hanya dapat mengembangkan kemampuan pada aspek kognitif, pembelajaran STEAM juga dapat mengembangkan kemampuan dan skill lain yang berguna bagi peserta didik untuk menghadapi tantangan era globalisasi di masa mendatang.

\section{REFERENSI}

Buinicontro, J. K. (2018). Gathering STE(A)M: Policy, Curricular, And Programmatic Developments In Arts-Based Science, Technology, Engeneering, And Mathematics Education Introduction To Special Issue Of Art Education Policy Review: STEAM Focus. Art Education Policy Review Journal. Volume 119, 2018 - Issue 2.

Fitri, R. 2014. Penerapan Strategi The Firing Line pada Pembelajaran Matematika Siswa Kelas XI IPS SMA Negeri 1 Batiputih. Jurnal Pendidikan Matematika UNP Vol 3 No 1

Hendriana, H., dan Soemarmo, U. 2014. Penilaian Pembelajaran

Matematika. Bandung: Refika Aditama.

Permendikbud. 2013. Kerangka Dasar dan Struktur Kurikulum Sekolah Menenga Pertama/Madrasah Tswnawiyah No 68.

Saputra, J. 2017. Pengaplikasian Teknologi dalam Pembelajaran STEAM pada Pelajaran Matematika. Diambil dari blog 
http://guraru.org/guruberbagi/pengaplikasianteknologi-dalam-pembelajaransteam-pada-pelajaranmatematika/ pada Februari 2019.

Suherman, E., dkk. 2003. Strategi Pembelajaran Matematika Kontemporer. Bandung: PT Remaja Rosdakarya.

Shadiq, F. 2019. Pembelajaran Matematika pada Era Industri 4.0. Suatu Tantangan Bagi Guru dan Pendidik Matematika. Prosiding pada Seminar Nasional Penelitian Pendidikan Matematika UMT.

Wijaya, A.D., dkk. 2015. Implementasi Pembelajaran Berbasis STEAM (Science, Technology, Engineering, Art, Mathematics) Pada Kurikulum Indonesia. Proseding pada Seminar Nasional Fisika dan Aplikasinya. Universitas Padjadjaran Bandung. Sabtu 21 November. 